\title{
Сполучуваність слів в українській мові XVI-XVII ст. Спроба лексикографічного опису
}

\author{
ГАННА ДИДИК-МЕУШ \\ Відділ української мови Інституту українознавства ім. І. Крип'якевича НАН України, \\ вул. Козельницька, 4, UA-79034 Львів \\ E-mail: hannadydyk@ukr.net
}

(Received: 1 April 2017; accepted: 4 July 2017)

\begin{abstract}
The aim of this paper is to present the compatibility of words in the Ukrainian language of 16th and 17th centuries based on the attributive-substantival complexes and the lexicographical attempt to describe these lexical units.

Keywords: Ukrainian, historical lexicography, relic text, attributive adjective, adjectivalsubstantive complexes, compatibility of words
\end{abstract}

Ад'єктивна лексика $є$, поза сумнівом, когнітивно-дискурсивним класом слів, тому що відображає найважливіші особливості сприйняття й осмислення людиною світу (АФАНАСьЕВА 1994, ЮдИНА 2006, КуБРЯкОВА 2007, WOLFGIBSON 2006). Із когнітивної точки зору, прикметник-атрибутив має означальне значення і чітку семантичну видільність (виокремлюваність): він позначає непроцесуальні ознаки суб'єкта, фіксуючи насамперед найбільш стійкі та постійні з них. Пропоноване дослідження базується на атрибутивно-субстантивних словосполученнях (далі- АCC) в українській мові XVI-XVII ст. у площині сполучуваності, яка є «потужним лінгвістичним інструментом семантичного опису і мовним доказом, підтвердженням правильності такого опису» (РАхилина 2000: 10). Аналізовані АСС кваліфікуємо як просте двочленне поєднання слів, у якому функцію стрижневого компонента виконує іменник, який перебуває в постпозиції стосовно контактно (рідше - дистантино) розташованого залежного від нього прикметника, поєднаного зв'язком узгодження. Саме такий порядок розташування компонентів зумовлений виключно препозицією прикметника, що виконує функцію узгодженого означення.

Зацікавлення АСС зумовлене кількома причинами: 1) словосполучення іменників із прикметниками становлять одну з найбільш регулярних, продуктивних і частотних груп у більшості мов флективного типу; 2) лексичну сполучуваність вивчають переважно на основі комбінацій дієслова з іншими частинами мови, очевидно, завдяки зручності опису синтагматичних можливостей дієслова; попри те що, принагідних зауваг про АСС у славістичному мовознавстві доволі багато, усе ще не представлено цілісного погляду на такі словосполучення, зокрема на концептуально-когнітивному рівні; 3) висвітлення проблеми сполучуваності слів у площині когнітивної лінгвістики посідає одне із чільних місць (АРУТЮНОВА 1999, БАРАНОВ 2003, БОГУСЛАВСКАЯ 
2006, ВЕНДЛЕР 1981, КОБРИНА 2005, КУБРЯКОВА 2004, КУБРЯКОВА 2007, ЛАКОФФ 2004, Никитин 1974, Никитин 1983, РАхилина 2000, Coulson 2001, FauconNIER-TURNER 2002 та ін.), проте зауважмо, таких робіт узагалі не існує на матеріалі української мови XVI-XVII ст.; 4) загальновідомо, що атрибутивний зв'язок $є$ найбільш тісним видом зв'язку, коли «два члени максимально зливаються, тобто представляють собою цілісну одиницю всередині речення i піддаються членуванню лише всередині того комплексу, який утворюють» (Смирницкий 1957: 176-177), «оформлюють не речення загалом, а відомий комплекс у його межах» (АХмАНОВА-МикАЭЛян 2003: 146). Цей факт, очевидно, пояснює регулярність появи все нових і нових таких словосполучень як одиниць номінації, які вкрай необхідні людині для спілкування, коли «явища, предмети та ін. потребують субкатегоризації, щоби суб'єкт міг вибрати єдину, „правильну“ на даний момент модель» (ЛАкоФФ 2004: 108). Навіть більше - у зв'язку зі зміною способу життя та діяльності, переломом у світогляді та зміною стереотипів мислення АСС з'являються з більшою регулярністю і як одиниці номінації, що об'єктивують зміни стосовно нових концептів, а також старих понять, що обростають новими когнітивними ознаками (ЮдинА 2006: 4). Такі номінативні одиниці важливо вивчати, оскільки виконують особливу функцію ідентифікації і виокремлення нових реалій із позицій когнітивно-дискурсивної парадигми дослідження мови. А застосування когнітивного підходу до аналізу АСС дає змогу здійснити глибшу інтерпретацію такої конструкції відповідно до ії місця в когнітивно-культурологічному просторі мови і засвідчити когнітивні операції, які розкривають композиційну семантику комплексних одиниць, їх концептуальну насиченість та особливості деяких глибинних ментальних процесів в іменному композиційному просторі української мови XVI-XVII ст.

У сучасній лінгвістиці більшість досліджень про АСС стосується переважно двох основних і чітко протиставлених груп - вільних і невільних (стійких) словосполучень. Проте, як свідчать матеріали пам'яток, особливість АCC у тому, що вони розташовані в проміжній зоні - між повністю вільними і повністю зв'язаними словосполученнями. Така «серединна» позиція зумовлена тим, що, з одного боку, АСС поводяться як вільні словосполучення, 3 іншої - мають тенденцію до аналітизму внаслідок синтезованості і цілісності загальних значень словосполучень, які складені із семантики двох окремих компонентів - іменника і прикметника.

Отож для опису таких АCC потрібно, окрім інтралінгвальних, враховувати також їх екстралінгвальні особливості. Основу типології, запропонованій у цій статті, визначають лінгвокогнітивні особливості АCC, де лінгвістичні особливості - це відомі й описані у класичній літературі відомості про мову, а когнітивні - це знання й уявлення людини про світ. Когнітивний підхід до мови трактуємо як такий, коли «робиться спроба поглянути на всі явища і процеси, одиниці і категорії тощо відповідно до їхнього зв'язку 3 іншими когнітивними процесами: зі сприйняттям і пам'яттю людини, ії уяви та емоцій, мислення», а «мову вивчають не тільки як унікальний об'єкт, 
що знаходиться в ізоляції, а й значною мірою і як засіб доступу до всіх ментальних процесів, які мають місце в голові людини і які визначають їі власне буття та функціонування в суспільстві» (КуьряковА 2004: 149).

Для зручності опису створено шкалу композиційної семантики проміжних типів АCC, в основі якої-когнітивно-композиційний принцип інтеграції значень (ЮдинА 2006). Шкала побудована залежно від ступеня вивідності / невивідності композиційної семантики із суми значення частин словосполучення за принципом: сполучуваність слів, об'єднаних у межах однакових (на перший погляд) конструкцій, може привести (і таки приводить) до різних семантичних наслідків. Ці результати залежать не стільки від лексичних значень слів, що входять до словосполучень, скільки від концептуальної взаємодії і взаємовпливу елементів конструкції. Тож, відповідно до такої концепції, на одному полюсі шкали перебувають вільні АСС (адамашковая лиштва, облако аирноє, оксамитная шапоска та ін.); на другому - повністю ідіоматичні і абсолютно немотивовані одиниці, що характеризуються невивідністю значень цілого із суми значень його частин (<будучи> цุалого умысллу, <оддати> до върныхъ рукъ та ін.).

Між цими полюсами є численні проміжні одиниці з різним ступенем не-свободи (за визначенням Н. В. Юдіної), які можна поділити на дві групи: 1) композиційно вільні, але лінгвістично невільні (кариє очи, битый шляхъ, cuвblє волосы та ін.) і 2) композиційно невільні, але лінгвістично вільні: а) вирази-кліше (благоє дђло, благая вђсть, божию милостию та ін.), б) етикетні (милосиъвыє панове, славетне товариство), в) словосполучення номінаційного типу (більшість із них $є$ термінами) - географічні назви, назви адміністративно-територіальних одиниць, юридичні, церковні, медичні та ін. терміни, назви календарних періодів і свят, назви страв, назви рослин, назви тварин, каменів (Африцккая земля, азовскоє море, апостолская столица, Великий пость, амброзієва трава, артетичная болезнь, агатовый камень, сторона акторская та ін.).

Такі АСС не тільки чекають свого детального вивчення та характеристики, а і є цінним матеріалом для лексикографічного опису, і в словниках посідають своє, окреме, місце, про що свідчить перша стпроба виділити окремо такі АСС проміжного типу, реалізована у книзі «Українські краєвиди XVI-XVIII ст. Слово - текст - словник» Г. Дидик-Меуш та О. Слободзяник (Дидик-МЕуш-Слободзяник 2015).

Нижче пропонуємо матеріали до майбутнього «Словника сполучуваності української мови XVI-XVII ст.» на основі атрибутивно-субстантивних словосполучень української мови того періоду. Реєстровим словом виступає виявлений у різножанрових текстах XVI-XVII ст. прикметник (чи ад'єктивований дієприкметник). Після реєстрового слова подано: 1) форму іменника, iз яким пов'язаний реєстровий прикметник; 2) форма-етимон та відповідник в інших слов'янських мовах того періоду (якщо необхідно); 3) значення (із покликанням на словники, коли при потребі звідти взято тлумачення); 4) АСС (зі значком •) для ілюстрації значення прикметника; 5) вказівка джерела, звід- 
ки ексцерповано ілюстрацію (СУМ XVI-XVII 1: 37-55); 6) спеціальним значком (••) марковано АСС так званого проміжного типу, а також стійкі словосполучення-ідіоми.

абшитованный прикм. від абшить

'відправлений зі служби' (Тимч. 4) (пор. ст.-пол. abszytowany)

• осаулъ абшитованный (1752 КТ)

• сотникъ абшитованный (1764 КТ)

- товаришъ абшитованный (XVIII ст. КТ)

авизоралный прикм. вid авизія (пор. ст.-пол. awisa iз фр. avis)

'повідомний' (СУМ XVI-XVII 1: 70)

•• листь авизоралный 'письмове повідомлення, сповіщення; повідомний лист' (Ісаїки, 1643 ДМВН 253)

авксильярный (лат. auxiliarius)

'помічний, посилковий' (Тимч. 6)

• войска авксильярныи (Вел. Сказ. 2 // КТ)

авонский прикм. від Афонъ

'пов'язаний з Афоном, афонський'

•• печать авонская (1739 КТ)

авраамовый прикм. від Авраамъ

'пов'язаний з Авраамом або належний йому, Авраамів'

• пастухъ авраамовый (поч. XVII ст. Проп.р. 182 зв.)

автентичный (автенътичний, автентычный) прикм. від автентикъ

'підтверджений, доказаний, справжній, достовірний, дійсний, автентичний' (СУM XVI-XVII 1: 71)

• позовъ <кгродский, винницкий> автентычный (Вінниця, 1622 ЛНБ 5, ІІІ 4057, 63)

- позовь <кгродский, чєрниговский> автенътичний

(Чернігів, 1641 ЛНБ 5, II 4063, 177)

- плястерь автентичный (XVIII ст. КТ)

агаронский прикм. вid агаряны ('магометани, мусульмани' - CУM XVI-XVII 1: 71)

'те саме, що агарянский'

• кроль агаронский (XVII ст. КТ)

агарянский прикм. від агаряны

'татарський' (Тимч. 7)

• языкъ агарянский (1697 КТ)

агатовъ прикм. від агать

'агатовий'

•• камень агатовъ 'агат' (CУM XVI-XVII 1: 72)

агиревь $п р и к м . ~ в і \partial ~$ аерь $^{2}$ 'аїр, татарське зілля, лепеха'

'пов'язаний $з$ аїром'

аглицкий

•• агиревъ корень ‘татарське зілля’ (XVI ст. КТ)

'англійський'

- земля аглицкая (ЛСЛ 128)

• сукни аглицкии (1719 КТ) 
адамантовый прикм. від адаманть

1. перен. '(твердий як сталь) незламний, непохитний' (СУМ XVI-XVII 1: 73)

- статечность адамантовая <въ вњрђ> (Київ, 1620 МІКСВ 32)

2. перен. 'який не викликає заперечень, переконливий'

- доводи адамантовыє (Київ, 1620 МІКСВ 32)

адамашковый (сдамашковый, одамашковый, ядамашковый) прикм. від адамашка

‘виготовлений з адамашки, адамашковий' (СУМ XVI-XVII 1: 74)

- взоръ адамашковый (Львів, 1637 Інв. 76)

• воздухъ адамашковый (1627 КТ)

- калытка адамашковая (Львів, 1637 Інв. 23 зв.)

- лиштва адамашковая (XVIII ст. КТ)

- пєтрахиль єдамашковый (Четвертин, 1610 ВИАС I, 10)

- рызы <червоныє> ядамашковыє (Луцьк, 1621 АрхЮЗР 1/VI, 502)

- рыза адамашковая (XVII ст. КТ)

- саръдакъ адамашковый (1572 КТ)

- чамара адамашковая (Житомир, 1609 ЦДІАК 11, 1, 5, 14 зв.)

- шуба одамашковая (Краків, 1539 AS IV, 184)

- шата одамашковая (Несухоїже, 1550 AS VI, 5)

аджамский (ачамский)

'перський' (СУМ XVI-XVII 1: 74, 148)

• кожух <бараний> ачамский (Житомир, 1584 АЖМУ 90)

•• коберецъ аджамский 'перський килим' (Житомир, 1605 ШДІАК 11, 1, 4, 13 зв.-14)

\section{адзямеский}

'те саме, що аджамский' (СУМ XVI-XVII 1: 74)

•• коберецъ адзямеский ‘перський килим’ (Київ, 1635 ЛНБ 5, II 4060, 105)

администраторский прикм. від администраторъ

'пов'язаний з адміністратором, адміністраторський'

- дієцезія администраторская (1694 КТ)

адмъралскій (адмиралский) прикм. від адмъраль

'пов'язаний з адміралом, адміральський'

- корабль адмиралскій (ЛСЛ 781)

- окрентъ адмиралский (XVIII ст. КТ)

адовъ (адовый, адовъй) прикм. від адъ

'пов'язаний із пеклом або який належить йому; пекельний' (CУM XVI-XVII 1:

75), 'що належить до Аду’ (Тимч. 8)

- брамы адови (Київ, 1625 Злат.Н. 130)

- ворота адовы (1556-1561 ПС 74)

- врата адови (Вільна, 1599 Ант. 911)

• конци адовыє <посльдныє> (1599 Виш.Кн. 214)

- кгмахи адовыє (XVI ст. НС 74)

- мъста адова (Четья, 48)

- пащеки адови (Реш.Св. 10 // КТ)

- пропасти адовъє (1599 Виш.Кн. 217)

- пропасть адова (Чернігів, 1646 Перло 26 зв.)

адский (адъский) прикм. від адъ

'те саме, що адовъ (СУМ XVI-XVII 1: 76), 'властивий Адові' (Тимч. 9) 
- вАзєНє аДъсКоє (XVII ст. КТ)

- мЂста адскиє <подзємныє таємныє> (Чернігів, 1646 Перло 128)

- мъсто адскоє (ЛСЛ 673)

- мученіє адскоє (ЛСЛ 175)

- окно адскоє (ЛСЛ 706)

- панство адскоє (1631 Волк. 24 зв.)

- пропасть адская (Почаїв, 1618 Зерц. 7 зв.)

- силы адьския (1489 Четья 333)

аєрный (аирный) прикм. від аеръ '`повітря’

'повітряний'

- воздухи аєрныє (1598 Виш.Кн. 310 зв.)

- облако аирноє (Чернігів, 1646 Перло 142)

аєровымыслный комп. прикм. від аєръ + вымыслный

'надуманий, неправдивий' (СУМ XVI-XVII 1: 77)

• книжки аєровымыслныи (1608-1609 Виш.Зач. 201)

азбуковный прикм. від азбука

'те саме, що азбучный'

- писмена азбуковная (XV ст. КT)

азбучный прикм. від азбука

'азбучний, алфавітний'

- льтеры азбучныи (1627 ЛБ 234)

•• порядокъ азбучный 'азбука'

азийский прикм. від Азия

'пов'язаний з Азією, азійський'

- страни азийскиє (XVIII ст. КТ)

азитицкий прикм. від Азия

'те саме, що азийский'

- Сармация <татарская або> азитицкая (XVII ст. КТ)

азиятицкий (азіятицкий) прикм. від Азия

'те саме, що азийский'

• манъеръ азіятицкий (1726 КТ)

- страни азиятицкие (XVIII ст. КТ)

азовский прикм. від Азовъ

'пов'язаний з Азовом, азовський'

•• море азовскоє (ЛСЛ 698)

академицкий прикм. від академия

'академічний' (СУМ XVI-XVII 1: 84)

- богословцы академицкиє <школныє> (Дермань, 1605 Мел.Л. 10)

аквавитый прикм. від аквавита (лат. aqua vitae, букв. 'вода життя')

'оковитий' (СУМ XVI-XVII 1: 84)

•• горилка аквавитая 'горілка, раз тільки дистильована' (Тимч. 13)

аксамитный (оксамитный) прикм. від аксамить

'виготовлений з оксамиту, оксамитовий' (СУМ XVI-XVII 1: 85)

- брама оксамитная (Луцьк, 1598 АрхЮ3Р 1/VI, 241)

- дылья оксаитная (Луцьк, 1563 PEA II, 127)

- єпєтрахиль аксамитный (Львів, 1579 ЛСБ 1034)

- жупанъ аксамитный (1600 КТ)

• колдра аксамитная (Київ, 1635 ЛНБ 5, II 4060, 104) 
• колпакъ оксамитный (Вільна, 1546 AS IV, 474)

• кунтушъ аксамитный (Вел.IV, 120 // КТ)

- летникъ аксамитный (Луцьк, 1622 АрхЮЗР 6/I, 430)

- лиштва аксамитная (XVII ст. КT)

- окладъ аксамитный (Львів, 1579 ЦДІАЛ 129, 1, 1114)

- пасаманъ оксамитный (Житомир, 1650 ДМВН 194)

- пахви аксамитныє (XVIII ст. КT)

- петрахиль аксамитный (Луцьк, 1621 АрхЮЗР 1/VI, 502)

- покритя оксамитныє (Луцьк, 1583 АрхЮЗР 1/I, 183)

- поясъ оксамитный (Луцьк, 1598 АрхЮЗР 1/VI, 242)

- саянъ оксамитный (Володимир 1573 АрхЮЗР 8/III, 245)

- ферезия аксамитная (Київ, 1635 ЛНБ 5, II 4060, 104, 105)

- чамара аксамитная (Володимир, 1631 АрхЮЗР 1/VI, 628)

- шапки аксамитныє (1750 КТ)

- шапка оксамитная (Ковель, 1585 ЖКК I, 261)

- шапочка оксамитная (Київ, 1633 ЛНБ 5, II 4060, 23 зв.)

- шаты аксамитныє (Житомир, 1647 ЏДІАК 11, 1, 12, 72)

- шуба оксамитная (Володимир, 1547 AS IV, 364)

актеоновъ прикм. від Актеонъ

'який стосується Актеона, Актеонів'

- песь актеоновъ (ЛСЛ 47, 98)

акторский прикм. від акторъ ('позивач')

'який позиває до суду'

•• сторона акторская ‘позивач’ (1693 КТ)

актуалный

'чинний, фактичний, правдивий' (Тимч. 15); пор. ст.-пол. aktualny

- интенцыя актуалная (1722 КТ)

алабастровый (алябастровый) прикм. від алабастръ ('сніжно-білий, дрібно зернястий гіпс' і 'слоїк, банька, алябастрове начиння' - Тимч. 20)

'виготовлений з алебастру, алебастровий' (лат. alabastrum)

• гробъ алябастровый (Київ, 1621 Коп.Пал. 1009)

- слоикъ алябастровый (1627 ЛБ 174)

•• камень алабастровый 'алебастр' (XVIII ст. КТ)

албанскій прикм. від Албания

'пов'язаний з Албанією, албанський'

• княжата албанскїи (1665 КТ)

алекторскій прикм. від алекторь 'півень'

•• камыкъ алекторскій (ЛСЛ 49)

алембиковый прикм. від алембикь 'прилад для дистиляції'

‘очищений, перегнаний на алембику' (Тимч. 17)

•• водка алембиковая 'чиста горілка' (XVIII ст. КТ) (Тимч. 17), пор. ст.-пол. alembikowa wódka

алемпардовый прикм. від лемпарть 'леопард'

'те саме, що лямпардовый, виготовлений зі шкури леопарда, леопардовий'

• попона алемпардовая (1744 КТ)

\section{алендерский}

'те саме, що голендерский; голландський' (Тимч. 17)

• кошуля алендерская (1744 КТ) 
александрїйский прикм. від Александрия

'пов'язаний з Александрією, александрійський'

•• Аөанасий Александрийский (XVII ст. КТ)

•• бумага александрїйская (ЛСЛ 175, 696)

•• война Александрийская (поч. XVII ст. Проп.р. 34)

алкермесовый прикм. від алкермесъ 'сироп із дубового черв'яка'

'виготовлений з алкермесу, алкермесовий' (Тимч. 18)

•• водка алкермесовая 'лікувальний алкермесовий настій' (XVIII ст. КТ)

аллегоричный (аллигорїчный, аллігоричный) прикм. від аллигоріа

'алегоричний' (СУМ XVI-XVII 1: 98), ‘переносний' (Тимч. 18)

- выкладъ <видЂнїА> аллігоричный (Вільна, 1627 Дух.б. 10)

• выкладъ <Моисєєвого законү> аллигорїчный (Вільна, 1627 Дух.б. 387)

- сенсъ аллегоричный (XVII ст. КT)

алмазный прикм. від алмазь

'діамантовий'

- крестъ алмазный (1743 КТ)

- перстень алмазный (1746 КТ)

алоесовый прикм. від алоесь

'який стосується алое, алоевий' (пор. ст.-пол. aloesowy)

•• древо алоесовоє (XVII ст. КТ)

алтабасовый (алтайбасовый) прикм. від алтабась 'алтабас, парча' (СУМ XVIXVII 1: 99), ‘тканина: основа шовкова, а піткання золоте’ (Тимч. 19)

'виготовлений з алтабасу, парчевий, алтабасовий' (СУМ XVI-XVII 1: 99)

- делиА алтабасовая (1558 AS VI, 214)

• копенякъ алтабасовый (XVII ст. КT)

• петрахиль алтабайсовый (Луцьк, 1621 АрхЮЗР 1/VI, 502)

алтембасовый прикм. від алтабасъ

'те саме, що алтабасовый'

- петрахиль алтембасовый (XVIII ст. КТ)

• коПенакъ алтембасовый (1596 Виш.Кн. 232 зв.)

- палица алтембасовая (XVIII ст. КТ)

- сакосъ алтембасовый (XVIII ст. КТ)

алхимицкий прикм. від алхимия

'який стосується алхімії, алхімічний' (СУМ XVI-XVII 1: 99)

• огни алхимицкіє (1646 КТ)

• робота алхимицкая (Київ, 1631 ПККДА II-1, 408)

алчебный прикм. від алчба 'піст'

'який стосується посту, постовий' (пор. цсл. алчьбьныли)

- даръ алчебный (1489 Четья 311)

альтембасовий прикм. від алтабась

'те саме, що алтабасовый' (СУМ XVI-XVII 1: 99)

• копенакъ альтембасовый (1596 Виш.Кн. 232 зв.)

- шаты алътембасовыє (Житомир, 1611 АрхЮЗР 3/I, 171)

амброзієвъ прикм. від амброзия

'виготовлений з амброзії, амброзієвий'

•• амброзієва трава 'трав'яниста рослина, амброзієва трава' (XVI ст. Травн. 28)

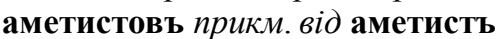

'аметистовий' 
•• аметистовъ камень 'аметист' (XVI ст. Травн. 490)

анаөематизованый $\partial і є п р и к м . ~ в і \partial$ анаөематизувати

(пор. ст.-пол. anatematyzować 'відлучати від церкви, проклинати')

'відлучений від церкви, проклятий церквою'

(СУM XVI-XVII 1: 103)

- єретикъ анаӨематизованый (XVII ст. КТ)

анделский

'те саме, що ангельский'(Тимч. 22)

• чистость анделская (XVII ст. Св.Реш. $306 / /$ КT)

ангеловъ (аггеловъ) прикм. від ангель

'пов'язаний з ангелом або належить йому; ангельський, діал. ангелів'

(СУМ XVI-XVII 1: 104)

- лице ангєлово (1489 Четья 106 зв.)

- намовы ангеловы (серед. XVII ст. Хрон. 387 зв.)

- пришествиє ангелово (1600-1601 Виш.Кр.отв. 170)

- руки аггловы (Львів, поч. XVII ст. Крон. 99 зв.)

- слово ангелово (1489 Чет. 16)

ангельский (ангелский, ангелскій, ангелскій)

'те саме, що ангеловъ; ангельський' (СУМ XVI-XVII 1: 104-105)

- животь ангелскій (Київ, 1637 УЄ Кал. 10)

- зборъ ангелский (к. XVI ст. 75)

- компанїи (поч. XVII ст. Проп.р. 192 зв.)

- легкость ангельская (XVI ст. УЄ Трост. 63)

- ликы ангелскиє (поч. XVII ст. Проп.р. 20)

- полки ангелскиє (к. XVI ст. Укр.п. 71)

- пьниє ангельскоє (поч. XVII ст. ПДПИ 182, 101)

- радость ангельская (1556-1561 ПЄ 287)

- ризи ангельские (XVIII ст. КТ)

- розумъ ангелскій (Львів, 1646 Жел.Сл. 5)

- руки ангелъскїє (Острог, 1607 ЛЪк. 85)

- силы ангельскиє (поч. XVII ст. Проп.р. 192 зв.)

- свьтло ангелскоє (Львів, 1630 Тр.П. 174)

- свђтлость ангельскаяє (XVII ст. КТ)

- сожитель ангелскій <блаженный Феодосій> (к. XVI ст. Укр.п. 88)

- трубенє ангельскоє (Чернігів, 1646 Перло 131)

- трубы ангельскїи (Львів, 1585 УС № 5, 21)

- уста ангельскиє (1599-1600 Виш.Кн. 48)

- хоры ангельскиє (Київ, 1637 УЄ Кал. 9)

- чистость ангельская (Реш.Св. $306 / /$ КТ)

•• ангелскій транусь трава (ЛСЛ 694)

•• войска ангелскиє (I пол. XVII ст. Сл. о зб. 26)

•• покармъ ангелский 'mе саме, щз хлъбъ ангелский' (Київ, 1634 МІКСВ 313)

•• староста ангельскїй 'архангел’ (1596 ЛЗ 24)

•• хльбъ ангелский 'манна $з$ неба' (Острог, 1599 Кл.Остр. 215)

•• чини ангельскии (1608-1609 Виш.Зач. 216)

англенский прикм. від Англия

'пов'язаний з Англією, англійський'

•• король англенский (1709 КТ) 


\section{англинский}

'те саме, що англенский; англійський'

•• король англинский (1709 КТ)

ангелскій прикм. від Англия

'те саме, що англенский; англійський' (пор. ст.-пол. angielsky)

•• король анкгелскій (XVIII ст. КТ)

ангурский

'виготовлений з ангорської вовни, ангорський'

(СУM XVI-XVII 1: 105)

- чалмьль анкгурский (Львів, 1617 ЛСБ 1043, 26 зв.)

анисный прикм. від анисъ

'анісовий, ганусовий'

•• анисная водка 'лікувальний анісовий настій' (ЛСЛ 83)

аномалный прикм. від аномалия

'аномальний' (СУМ XVI-XVII 1: 110)

- имена аномалныє (Єв’є, 1619 См.Грам. 4)

антидорный прикм. від антидоръ 'частина великої проскури, антидор'

'призначений для антидору, антидорний'

- блюдо антидорноє (Київ, 1646 Мог.Тр. 247)

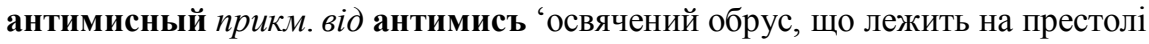
у церкві' (Тимч. 25)

'пов'язаний з антимісом, антимісний'

- губа антимисная (XVII ст. КТ)

антихристовъ (анътихристовъ) прикм. від антихристь

1. 'який належить антихристові, антихристів'

- гнђздо антихристово (1608-1609 Виш.Зач. 227)

- предытечъ антихристовы (серед. XVII ст. ЛЛ 165)

- слугы антихристовы (серед. XVII ст. ЛЛ 165)

- царство антихристово (Вільна, 1595 Ун.гр. 156)

2. 'подібний до антихриста, злий, нечестивий, підступний, диявольський, антихристів' (СУМ XVI-XVII 1: 111)

- въра антихристова (Львів, 1605-1606 Перест. 56)

- законъ анътихристовъ (1596 Виш.Кн. 261)

- лжепророци антихристови (XVII ст. КТ)

- окрутеньство антихристово (XVI ст. КАЗ 643)

антоновъ прикм. від Антоний

'пов'язаний зі св. Антонієм або належний йому; антонієвий'

•• огонь антоновъ 'гангрена' (ЛСЛ 143; 1060); пор. ст.-пол. ogień świętego Antoniego (за переказами, мощі св. Антонія допомагали при гангрені - дет. див. Дидик-МЕуш 2008: 289-290)

анъмушный прикм. від анъмушъ 'дух, серце, характер, душа' і 'мужність, відвага'

(Тимч. 23) (пор. ст.-пол. animusz із лат. animus)

'мужній, відважний' (Тимч. 23)

• кони аньмушныє (XVII ст. КТ)

- люди аньмушныє (XVII ст. КТ)

анъмушоватый прикм. від анъмушь

'повний анімушу, зуховатий' (Тимч. 23)

• кони аньмушныє (XVII ст. КТ) 
аполинарневый прикм. від Аполинарий

'який стосується науки, проповідуваної сектою аполінаристів'

(СУM XVI-XVII 1: 115-116)

- єресь аполинарневая (поч. XVII ст. Волк.В. 74)

апостатский прикм. від апостать

'відступницький'

• дымъ апостатский (Київ, 1621 Коп.Пал. 654)

- дыханиє апостатскоє <унитскоє> (Київ, 1635 КПМП І, дод. 266)

апостолический прикм. від апостоличество

'православний' (СУМ XVI-XVII 1: 117)

• өронъ апостолический <Константинополский> (Київ, 1634 КМПМ І, дод. 555)

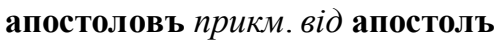

'пов'язаний з апостолом (апостолами) або належний йому (їм), апостолів'

•• мъсце апостолово ‘уривок із Діянь апостолів’ (1603 Пит. 102)

апостольский (апостолский, апостолскій) прикм. від апостоль

1. 'який стосується апостола (апостолів), апостольський'

• глаголь апостолский (Київ, 1648 МІКСВ 349)

• ликъ апостольский (Львів, 1605-1606 Перест. 47)

• плечь апостольскиє (1489 Чет. 265)

- постъ апостольский (Київ, 1619 О обр. 157)

- слова апостолскиє (Вільна, 1595 Ун.гр. 154)

- руки апостолские (II пол. XVI ст. КА 135)

2. 'організований, проповідуваний апостолами, апостольський'

- наука апостолская (1603 Пит. 41)

- правила апостолскиє (Львів, 1586, ЦДІАЛ 129, 1, 68)

- проповъданиє апостольскоє (Перемишль, 1592 ЛСБ 399)

- проповьдь апостолская (1608-1609 Виш.Зач. 202)

- учениє апостолскоє (Львів, 1614 Вил.соб. 2)

- чоуда апостолскиє (поч. XVII ст. Проп.р. 228 зв.)

•• бесьды апостолскиє 'книга проповідей' (Луцьк, 1627 ПВКРДА I-2, 265)

•• дьяния апостолскиє 'Діяння апостолів’ (Вільна, 1599 Ант. 801)

•• дъи апостолскыє 'Діяння апостолів' (поч. XVII ст. Проп.р. 100 зв.)

•• дъйма апостольская (дъйма 'діяння') 'п’ята книга Нового Завіту про діяння апостолів Петра і Павла; Діяння апостолів’ (XVI ст. НС 151) = дъяния апостольскис, дъи апостолскыс

•• канонъ апостолский (Львів, 1646 Зобр. 36 зв.)

•• книги апостолскиє (XVII ст. КТ)

•• листи апостолскиє 'книга апостольських проповідей' (поч. XVII ст. Проп.р. 150 зв.)

•• писаниє апостолскоє (1489 Чет. 48)

•• писмо апостолскиє

•• правило апостолскоє

•• право апостолскоє

•• преданє аполстолскоє (Львів, 1586, ЦДІАЛ, 129, 1, 68)

•• сльдъ апостолский

•• соборъ апостолский

3. 'який стосується послідовників апостолів, апостольський'

- єпископы апостолскии (Вільна, 1596 Ун.гр. 134) 
• мужъ апостолскій (Київ, 1621 Коп.Пал. 777)

4. 'який стосується католицької церкви, католицький'

•• вЊра <правдиваА, святая> апостолскаА 'католицизм' (Чернігів, 1646 Перло 12)

•• намъстникъ апостольский 'Папа Римський'

•• столица апостольская ‘Рим, Ватикан’ (поч. XVII ст. Проп.р. 234 зв.)

•• церковъ апостольская 'католицька церква' (Львів, 1596 ЛСБ 301, 1 зв.)

апполиновый прикм. від Аполлонъ

'пов'язаний з Аполлоном або належний йому; аполлоновий'

• божница апполиновая (поч. XVII ст. Проп.р. 291 зв.)

априлевый прикм. від априль

'пов'язаний із місяцем квітнем, квітневий' (СУМ XVI-XVII 1: 118)

• рочки априлевыє <кгродскиє Луцкиє> (Луцьк, 1643 КМПМ II, 271)

аптекарский (аптикарский) прикм. від аптекаръ

1. 'аптекарський, лікарський'

- робота аптекарская (серед. XVII ст. Хрон. 108 зв.)

2. 'аптечний, лікувальний'

- ложка аптекарская (ЛСЛ 198, 775)

- рурка аптикарская (ЛСЛ 1243)

- товарь аптекарский (Володимир, 1616 ТУ 260)

- художество аптекарскоє (ЛСЛ 1407)

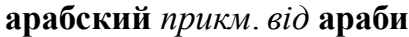

'те саме, що аравитский; арабський'

- король арабский (XVII ст. КТ)

аравитский (аравитскій, аравицкий) прикм. від Аравия

'арабський'

- звђръ аравитскій (ЛСЛ 11)

- земля аравитская (XVI ст. КT)

- злото аравитскоє (XVII ст. КТ)

•• гори аравицкиє (XVIII ст. КТ)

•• камень аравитскїй желвїй (ЛСЛ 198)

аравский прикм. від Аравия

'те саме, що аравитский'

- земля Аравская (XVII ст. КT)

- птица аравская кинамологъ (ЛСЛ 278)

арапский (арапъский) прикм. від арапь

'те саме, що аравитский, арабский' (СУМ XVI-XVII 1: 120)

- земля арапская ефіопія (ЛСЛ 41)

- страны арапьскиє (XVI ст. Травн. 129)

- царство Арапскоє (XVII ст. КТ)

араратскый прикм. від Арарать

'араратський'

•• гори араратскыє (поч. XVII ст. Проп.р. 272 зв.)

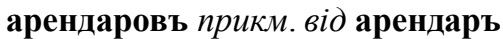

'пов'язаний з орендарем або належний йому, орендарів'

• слуги арендаровыє (1605 КТ)

арендовный прикм. від аренда'

1. 'пов'язаний з орендою, який орендує, орендний' 
- державца арендовный (1586 КТ)

- гроши арендовныє (1678 КТ)

- контракт арендовный (XVIII ст. КТ)

- шафаръ арендовный (1691 КТ)

2. 'взятий в оренду, орендований'

- добра арендовъныє (1649 КТ)

• пожитки арендовныє (1569 КТ)

- шинокъ арендовный (1691 КТ)

•• листь арендовний 'письмовий дозвіл на орендування майна; орендний лист' (Горохів, 1593 ПККРДА І-2, 158)

•• право арендовноє 'право на орендування майна'

арештовный прикм. від арештъ; пов'язаний із арештом' (СУМ XVI-XVII 1: 124)

•• година арештовная 'визначена пора, коли обвинувачений має з'явитися перед судом’ (Київ, 1607 ЛНБ 5, II 4052, 28)

•• листь арештовный 'лист про заборону чого-небудь' (1706 КТ)

арештовый 'те саме, що арештовный'

•• година арештовая 'те саме, що година арештовная'

•• листь арештовый 'документ на арешт’ (Луцьк, 1627 АрхЮЗР 1/VI, 581)

•• ресстръ арештовый (1618 КТ)

аристотелевъ прикм. від Аристотель

'пов'язаний з Арістотелем або належний йому; Арістотелів'

- книги аристотелевы (ЛСЛ 64)

аристотслский 'те саме, що аристотелевъ; Арістотелів, Арістотелевий'

•• наоука <аристотє(л)скаА> философскаА (XVII ст. Проп.р. 123 зв.)

арітметичний прикм. від аритметика

'пов'язаний з арифметикою, арифметичний, математичний'

- арітметічна книжка (1739 КТ)

арїанский (аріанский, аръриянский, ориянский) прикм. від арїяни

'пов'язаний з аріанами або аріанством; аріанський'

- блюзньрство арїанскоє (Київ, 1646 Мог.Тр. 905)

- въра аріанская (XVII ст. КT)

- єрєсь арї̈анская (XVI ст. УЄ № 29515, 264)

- постановена аръриянскиє (Вільна, 1599 Ант. 599)

- секта ориянская (Володимир, 1648 АрхЮ3Р 1/VI, 820)

аркушовый 'прикм. від аркушъ; мірою, форматом в аркуш' (Тимч. 32)

- букварь аркушовій (Вел. III, 417 // КТ)

- книги аркушовыє (1734 КТ)

- мъра аркушовая (1662 КТ)

- шиба аркушовая (1724 КТ)

арматный (гарматний) прикм. від армата

1. 'гарматний'

- куля арматная (XVIII ст. КT)

2. 'пов'язаний з артилерією, артилерійський'

• асауль арматный (1690 КТ)

• пострђлъ арматный (XVIII ст. Вел. IV, 61 // КT)

3. 'озброєний'

- войска арматныє (XVII ст. КT)

- люди арматныи (Луцьк, 1639 АрхЮЗР 1/VI, 751) 
•• писаръ гарматный ‘військовий писар' (СУМ XVI-XVII 1: 128)

армениновъ прикм. від арменинъ

'пов'язаний з вірменином, належний йому; вірменський'

- домъ армениновъ (1552 ОКЗ 40 зв.)

арменский прикм. від Армения

'пов'язаний з Вірменією, вірменський'

- княжа арменсоке (XVII ст. КТ)

- края арменскиє (XVII ст. КT)

• монастыръ арменский (1704 КТ)

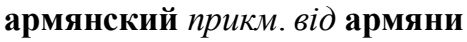

'пов'язаний з вірменами, вірменський'

- шапка армянская <баранковая> $(1724$ KT $)$

арнаутский прикм. від арнауты

'пов'язаний з арнаутами, арнаутський'

• языкъ арнаутский (Гр.Барск. I, 212 // КТ)

ароматный прикм. від аромать

'ароматний, запашний'

- угль ароматный (ЛСЛ 150)

арсеналный прикм. від арсеналь ‘місце, де переховуються кораблі’ (Тимч. 34)

'пов'язаний з арсеналом, арсенальний'

- врата арсеналныє (XVIII ст. КТ)

артетичный прикм. від артетика

'пов'язаний з артритом, артритний'

•• болезнь артетичная 'артрит' (XVIII ст. // КТ)

артилерійный прикм. від артилерія

'артилерійний, вогнепальний'

• капитанъ артилерійный (1726 КТ)

архангельский (архаггельский) прикм. вid архангель

'пов’язаний з архангелом, архангельський'

- стояния архангелская (1489 Чет. 43)

- рьчи <радостныє> архангельскиє (1489 Четья 52 зв.)

- чинъ архаггелъский (Почаїв, 1618 Зерц. 5)

архиєпископский прикм. від архиєпископь

'пов'язаний з архієпископом, архієпископський'

- добра аръхиєпископъскиє (Володимир, 1598-1599 Відп.ПО 1063)

- неблагословенє архиєпископъскоє (Гологори, XVI ст. Апол. 4)

- печать архїєрископская (Київ, 1628 Апол. 4)

•• столица архїєпископьская (Львів, 1591 ЛСБ 155)

архиєрєйский (архиєрейскїй, архіерейский, архїєрейскій) прикм. від архиєрей

'пов'язаний з архієреєм; архієрейський'

- голосове архієрейскиє (Володимир, 1571 УЄ Вол. 82)

- дворъ архиєрейский (поч. XVII ст. Проп.р. 93)

- молитвы архиєрейскиє (Іркліїв, 1650 ШДАДА 124, 3, 37)

- пілат архїєрейскій (Володимир, 1571 УЄ Вол. 82)

- поклонъ архиєрейскій (Дермань, 1628 КМПМ I, дод. 322)

- станъ архієрейский (Львів, 1614 Кн. о св. 3 зв.)

- шапка архіерейская (ЛСЛ 53)

• өронъ архїєрейскій (Київ, 1633 Евф. 308) 
архиєреовъ (архієреовъ, архїєрьєвъ) прикм. від архисрей

'те саме, що архисрейский; архієреїв'

- въра архїєрђєва (1489 Чет. 26)

- дворъ архиєрєовъ (XVII ст. КТ)

- служебникъ архиєрєовъ (1556-1561 ПЄ 317)

- вьра архїєреова (1489 Чет. 26)

- дворъ архїєреовъ (1556-1561 ПЄ 109 зв.)

- служебникъ архиєреовъ (1556-1561 ПЄ 317)

архимандритий прикм. від архимандрить

'те саме, що архимандритовъ'

•• рука архимандритья 'підпис' (Київ, 1592 АСД I, 186)

архимандритовъ прикм. від архимандрить

'пов'язаний з архімандритом або належний йому, архимандритів'

- врддникъ архимандрытовъ (Пісочне, 1541 AS VI, 281)

- люди аръхимандритовыє (1552 ОКЗ 46)

- спњваки архимандритовые (Львів, 1631 ЛСБ 1051, 5 зв.)

архимандритский прикм. від архимандрить

'те саме, що архимандритовъ; архімандритський'

• именя архимандритскиє (Луцьк, 1571 АрхЮЗР 8/VI, 364)

- прєложєнство архїмандритсокє (Вільна, 1620 См.Каз. 16 зв.)

арихмандрический прикм. від архимандрить

'те саме, що архимандритовъ, архімандритський' (СУМ XVI-XVII 1: 135)

- забава архимандрическая (Львів, 1631 ОЛ 16)

архимандричий (архимандрычий) прикм. від архимандрить

'те саме, що архимандритовъ; архімандритський'

- деспекть архимандричий (Дубно, 1575 АСД IV, 17)

- урадъ архимандрычий (Київ, 1631 Тр.П. 8)

•чинъ архимандричий (1594 КТ)

• чоловекъ архимандричий <печерский> (Київ, 1545 АрхЮЗР 1/VI, 44)

архимандрычинъ прикм. від архимандрить

'те саме, що архимандритовь' (СУМ XVI-XVII 1: 135)

- врядникъ архимандрычынъ (Луцьк, 1570 АрхЮЗР 1/I, 19)

архистратиговъ прикм. від архистратигь

'пов'язаний з архистратигом, архістратигів'

- царство <михаилово> архистратигово (1489 Чет. 373 зв.)

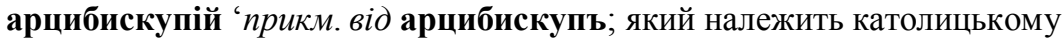
архієпископові'

- камяница арцибискупяя (серед. XVII ст. ЛЛ 167)

арцыкНАЖатскї̆

'великокнязівський, великокняжий' (СУМ XVI-XVII 1: 138)

- листы арцыкнАжатскї (Єв’є, 1616 Прич. отех. 3)

асесорский прикм. від асесорь

'асесорський, судовий' (СУМ XVI-XVII 1: 139)

- декретъ асъсесорский (Луцьк, 1648 АрхЮЗР 1/VI, 817)

•• судъ асесорский (1597 КТ)

аспидный прикм. від аспидъ

'диявольський, гаспидський'

• злоблениє аспидноє (1489 Четья 274) 
• ядъ аспидный (Острог, 1587 См.Кл. 6 зв.)

•• адъ аспидный 'злоба' (Острог, 1587 См.Кл. 6 зв.)

аспидовъ прикм. від аспидъ

'зміїний'

- ядъ аспидовъ (Київ, 1637 УЄ Кал. 543)

асписовый прикм. від асписъ 'дорогоцінний камінь, аспід, аспис'

(СУМ XVI-XVII 1: 141)

'пов'язаний з асписом, асписовий'

•• камень асписовый 'яшма' (XVI ст. КАЗ 605)

аспрный прикм. від аспра 'дрібна срібна монета'

'пов’язаний із грішми, грошовий' (СУМ XVI-XVII 1: 141)

• нужди аспрныє (1610 Виш.Посл. до Кн. 235)

ассерїйстїй прикм. від Ассирия

'пов'язаний з Ассирією, ассирійський'

- жолнђрє ассерїйстїи (поч. XVII ст. Проп.р. 274 зв.)

ассирийскый прикм. від Ассирия

'пов'язаний з Ассирією, ассирійський'

- кроль ассирийскый (XVII ст. КТ)

астрономский прикм. від астрономия

'астрономічний'

•• миля астрономская (СУМ XVI-XVII 1: 143)

атамановъ (отамановъ) прикм. від атаманъ

'належний отаманові; отаманів' (СУМ XVI-XVII 1: 142-143)

- домъ отамановъ (Київ, 1590 ЦДІА Лен. 823, 1, 133, 73 зв.)

- сынъ атамановъ (Житомир, 1618 АрхЮЗР 3/I, 213)

атаманский прикм. від атаманъ

'пов'язаний з отаманом, отаманський'

• позволенє атаманскоє (1665 КТ)

атєнскій прикм. від Атены

'пов'язаний з Атенами (Афінами), афінський, атенський'

- гєтманъ [царъ] атенскїй (поч. XVII ст. Проп.р. 260 зв.)

- млодснцы [юнаки] атенскїи (поч. XVII ст. Проп.р. 273)

- царъ атенскій (поч. XVII ст. Проп.р. 161 зв.)

атласовый (атъласовый, гатласовый, отласовый) прикм. від атласъ

'виготовлений з атласу, атласовий, атласний'

- аирь атласовый (1663 КТ), тут: 'накриття для чаші з Причастям; воздух' (СУМ XVI-XVII 4: 175)

- жупанъ атласовый (1676 КТ)

- колъдра атласовая (Київ, 1635 ЛНБ 5, II 4060, 104)

- материя атласовая (1688 КТ)

- матерацъ атъласовыи (Житомир, 1650 ДМВН 193)

- ризы гатласовыи (Львів, 1579 ЛСБ 1033, 1)

- сакосъ атласовый (Львів, 1637 Інв. 55)

• стихаръ атласовый (1675 КТ)

- шата отласовая (Тороканів, 1555 ЧИОНЛ V-3, 158)

аулный прикм. від ауль

'пов'язаний з аулом, аульний'

- татаре аулныє (1725 КТ) 
афинійский прикм. від Афины

'пов'язаний з Афінами, афінський'

афїнский

- ладїя афинійская (ЛСЛ 885)

• праздник афїнский (ЛСЛ 879)

африцкий прикм. від Африка

'пов'язаний з Африкою, африканський'

•• земля Африцкая (XVII ст. КТ)

Змога подати АСС у форматі словника дасть змогу уповні відобразити корпус таких словосполучень, сформований на основі текстів пам'яток української мови XVI-XVII ст. А це слугуватиме надійною підставою для відтворення повної картини уявлень тогочасних українців про себе і про світ.

\section{Литература}

АРУТЮНОВА 1999 = АРУТЮНОВА Н. Д. Язык и мир человека. Москва, 1999.

АФАНАСЬЕВА 1994 = АФАНАСЬЕВА О. Адъективный класс лексики в современном английском языке и формы его языковой репрезентаџии. Москва, 1994.

АХМАНОВА-МИКАЭЛЯН 2003 = АХМАНОВА О. С., МИКАЭЛЯН Г. Б. Современные синтаксические теории. Москва, 2003.

БАРАНОВ 2003 = БАРАНОВ А. Н. О типах сочетаемости метафорических моделей. Вопросы языкознания 2003/2: 73-94.

БОГУСЛАВСКАЯ 2006 = БОГУСЛАВСКАЯ О. Ю. ИнТеЛлеКТУаЛЬНЫе способности и деятельность человека в зеркале прилагательных. В кн.: Языковая картина мира и системная лексикография. Москва, 2006. 471-516.

ВЕНДЛЕР 1981 = ВЕНДЛЕР 3. О слове good. В кн.: Новое в зарубежной лингвистике. Вып. 10. Лингвистическая семантика. Москва, 1981. 531-554.

Дидик-МЕуш 2008 = Дидик-МЕуш Г. Українська медицина. Історія назв. Львів, 2008.

Дидик-МЕуш-СлоБодзяник 2015 = Дидик-МЕуш Г., СлоБодзяник О. Украӥнські краєвиди XVI-XVIII cm. Слово-текст-словник. Львів, 2015.

КоБРИНА 2005 = КоБРИНА Н. А. О соотносимости ментальной сферы и вербализации. В кн.: КубряковА Е. С. (ред.) Концептуальное пространство языка. Тамбов, 2005. 77-94.

КТ = Картотека «Історичного словника українського языка». За ред. С. Тимченка. Зберігається у відділі української мови Інституту українознавства ім. І. Крип’якевича НАНУ, м. Львів.

КуБРяковА 2004 = КуБРякоВА Е. С. О нетривиальной семантике в сочетаемости прилагательных с существительными. В кн.: АПРЕСян Ю. Д. (ред.) Сокровенные смысльл. Слово. Текст. Культура. Москва, 2004. 148-153.

КуБРякОВА 2007 = КуБРяковА Е. С. К проблеме ментальных репрезентаций. Boпросы когнитивной лингвистики 2007/4: 8-16.

ЛАКОФФ 2004 = ЛАКОФФ Дж. Женщины, огонь и опасные вещчи: что категории языка говорят нам о мышлении. Москва, 2004.

Никитин 1974 = Никитин М. В. Лексическое значение в слове и словосочетании. Владимир, 1974.

Никитин 1983 = Никитин М. В. Лексическое значение слова: структура и комбинаторика. Москва, 1983. 
РАХИЛИНА $2000=$ РАХИЛИНА Е. В. Когнитивный анализ предметных имен: семантика и сочетаемость. Москва, 2000.

СмиРницкий 1957 = СмиРницкий А. И. Синтаксис английского языка. Москва, 1957. СУМ XVI-XVII = ГРИНЧИшИН Д., ЧІкАлО М. (ред.) Словник украӥнської мови XVIпершої половини XVII cm. Вип. 1-16. Львів, 1994-2013.

Тимч. = Тимченко Є. Історичний словник українського языка. Харків-Київ, 19301932.

ЮдинА 2006 = ЮдинА Н. В. Лексическая сочетаемость в когнитивном аспекте (на материале конструкиии «прилагательное + существительное»). Москва, 2006.

Coulson 2001 = Coulson S. Semantic Leaps. Frame-Shifting and Conceptual Blending in Meaning Construction. Cambridge, 2001.

FAUCONNIER-TURner 2002 = FAUCONNIER G., TURner M. The Way We Think. Conceptual Blending and the Mind's Hidden Complexities. New York, 2002.

Wolf-GibSOn 2006 = Wolf F., GiBSon E. Coherence in Natural Language. Data Structures and Applications. Cambridge-London, 2006. 